\title{
FORMULASI NANOPARTIKEL EKSTRAK TEMU LAWAK BERBASIS KITOSAN SEBAGAI ANTIJERAWAT
}

\section{NANOPARTICLES FORMULATION OF TEMULAWAK EXTRACT BASED ON CHITOSAN AS ANTIACNE}

\author{
Syarmalina $^{1}$, Deny Wirawan ${ }^{1}$, Deni Rahmat ${ }^{1}$ \\ ${ }^{1}$ Fakultas Farmasi Universitas Pancasila, Jalan Srengseng Sawah, Jagakarsa, Jakarta Selatan
}

Submite : 02 Agustus 2018

Review : 27 Desember 2019

Accepted : 26 Maret 2019

\begin{abstract}
ABSTRAK
Kurkumin dalam ekstrak temulawak memiliki khasiat sebagai antiacne karena dapat menghambat salah satu bakteri penyebab jerawat yakni Propionibacterium acne. Tujuan penelitian ini adalah untuk memformulasi nanopartikel dari ekstrak temulawak. Ekstrak temulawak dan nanopartikelnya ditentukan nilai diameter daya hambat terhadap bakteri Propionibacterium acne. Pembuatan nanopartikel menggunakan kitosan dengan metode gelasi ionik. Nanopartikel yang terbentuk dikarakteristik ukuran partikel, zeta potensial dan morfologinya. Hasil menunjukkan bahwa nanopartikel mempunyai aktivitas antibakteri lebih besar daripada ekstrak temulawak. Nanopartikel mempunyai ukuran partikel $62,6 \pm 16,3 \mathrm{~nm}$, zeta potensial $-44,84 \pm 7,93 \mathrm{mV}$ dan bentuk speris. Dengan demikian nanopartikel ekstrak temulawak mempunyai potensi yang lebih besar untuk dikembangkan menjadi sediaan antiacne daripada ekstrak temulawak.
\end{abstract}

Kata kunci: ekstrak, temulawak, kitosan, nanopartikel, antibakteri.

\begin{abstract}
Curcumin in temulawak extract has antiacne properties because it can inhibit one of the acne-causing bacteria, Propionibacterium acne. The aim of this study was to formulate nanoparticles from curcuma extract and to evaluate its antibacterial activity. The value of inhibitory diameter of temulawak extract and its nanoparticles were determined against Propionibacterium acne. The nanoparticles preparation used chitosan with ionic gelation method. The nanoparticles formed were characterized for their particle size, potential zeta and morphology. The results showed that nanoparticles had greater antibacterial activity than curcuma extract. Nanoparticles showed a particle size of $62.6 \pm 16.3$ $\mathrm{nm}$, zeta potential of $-44.84 \pm 7.93 \mathrm{mV}$ and spherical shape. Thus temulawak extract nanoparticles have greater potential to be developed as antiacne preparations than curcuma extract.
\end{abstract}

Keywords : extract, temulawak, chitosan, nanoparticles, antibacterial.

Penulis korespondensi:

Syarmalina

Universitas Pancasila

Srengseng sawah Jakarta selatan

Email : mangnden78@yahoo.com

\section{PENDAHULUAN}

Obat-obat tradisional dapat berasal dari tumbuhan, hewan dan mineral. Umumnya obat-obatan tradisional minim akan efek samping sehingga dapat dikatakan aman bagi tubuh bila dikonsumsi. Salah satu tanaman berkhasiat sebagai obat yang sering digunakan dan telah terbukti khasiatnya adalah temulawak (Curcuma xanthorriza Roxb). Temulawak merupakan salah satu jenis temu-temuan marga Zingiberaceae dan telah diakui sebagai "ginseng Indonesia" karena manfaatnya yang beragam untuk kesehatan manusia (Afifah,2003).

Temulawak memiliki banyak khasiat dan telah banyak digunakan sebagai bahan obat tradisional. Khasiatnya antara lain, sebagai hepatoprotektif, penambah nafsu makan, mengobati diare, 
sembelit, pegal linu penyakit kuning dan mengatasi gangguan sekresi empedu. Didalam temulawak terkandung zat yang berkhasiat salah satunya yakni kurkumin. Menurut penelitian Retno Widiowati Soebaryo Pusat Klinik Kecantikan Tradisional membuktikan bahwa temulawak dengan kandungan kurkumin dapat menghambat patofisiologi jerawat yang salah satunya disebabkan oleh bakteri Propionibacterium acnes (Retno,1985; Reiger, 2000)

Pembuatan nanopartikel dapat menggunakan beberapa metode diantaranya penguapan pelarut, metode emulsifikasi dan metode gelasi ionik . Diantara metode-metode tersebut, metode gelasi ionik dinilai sebagai metode yang paling mudah dilakukan. Metode gelasi ionik melibatkan proses sambung silang antara polielektrolit dengan adanya pasangan ion multivalennya. Gelasi ionik seringkali diikuti dengan kompleksasi polielektrolit dengan polielektrolit yang berlawanan. Pembentukan ikatan sambung silang ini akan memperkuat kekuatan mekanis dari partikel yang terbentuk (Iswandana, Anwar,Jufri, 2012).

Pada percobaan ini akan dilakukan pembuatan ekstrak etanol $70 \%(\mathrm{v} / \mathrm{v})$ dari rimpang temulawak dan nanopartikel dengan menggunakan basis kitosan dan dilakukan uji aktivitas antiacne terhadap bakteri Propionibactericum acnes. Hal ini dilakukan untuk melihat apakah dengan pembuatan nanopartikel akan merubah aktivitas antiacne atau tidak.

\section{METODE PENELITIAN}

\section{Alat dan Bahan}

Alat : Inkubator (Memmert), homogenizer, viskometer (Brookfield Tipe RV), timbangan analitik, $\mathrm{pH}$ meter digital (Hanna HI 2211), alat-alat gelas, spray dryer (mini sprydryer Buchi 280), scaning electron microscope (SEM), alat pengukur zeta potensial, cawan petri, tube, dan kertas cakram steril. Bahan : Ekstrak Etanol Temulawak (Balitro, Bogor), Carbopol Ultrez 10 (Probig Fine Chemical Co, Guangzhou, China) dan bahan tambahan Trietanolamin (Petronas), Propilenglikol, Dinatrium EDTA, Metil paraben (Ueno Fine Chemical), Propil paraben (Ueono Fine Chemical), Natrium metabisulfit (PT. Brataco), Air suling, Media Mueller Hinton Agar, Kaldu Pepton, Kitosan (Biotech Surindo), NaTrpolifosfat (Hubei Xingfa Chemical)

\section{Jalannya Penelitian}

1. Penyediaan Bahan Penelitian

Rimpang temulawak yang digunakan dalam penelitian ini diperoleh dari Balitro, CimangguBogor, yang diperoleh pada umur kurang lebih 9 bulan.

2. Pembuatan Ekstrak Etanol Temulawak

Bahan yang digunakan adalah ekstrak etanol temulawak (Curcuma xanthorriza Roxb) yang diperoleh dari Balitro, Bogor, pelarut yang digunakan etanol $70 \%$ secara maserasi berulang (Ramdja, Aulia, Mulya, 2009).

3. Pembuatan Nanopartikel dari Ekstrak Etanol Temulawak

Kitosan sebanyak 1 gram dilarutkan dalam $100 \mathrm{~mL}$ asam asetat glasial $1 \%$ menggunakan magnetik stirer sehingga diperoleh konsentrasi kitosan 1\%. Sebanyak $500 \mathrm{mg}$ ekstrak etanol temulawak ditambahkan pelarut campur $(20 \mathrm{~mL}$ propilenglikol : $20 \mathrm{~mL}$ etanol $70: 20 \mathrm{~mL}$ DMSO 10\%) dan $100 \mathrm{~mL}$ aquadest. Kemudian ditambahkan larutan kitosan $1 \%$ sebanyak 40 $\mathrm{mL}$ sehingga konsentrasi kitosan menjadi 0,2\%. Campuran tersebut diaduk dengan menggunakan magnetic stirer selama 10 menit. Selanjutnya ditetesi dengan $20 \mathrm{~mL}$ Na-TPP 0,4\% dengan kecepatan 1 tetes / 3 detik dengan buret dan dalam magnetik stirrer dengan rpm 300 hingga terbentuk nanopartikel yang ditandai dengan kekeruhan yang homogen. Lalu tetap diatas magnetik stirrer selama 15 menit supaya didapat larutan nanopartikel ekstrak temulawak yang stabil. Kemudian diamati kestabilan larutan nanopartikel ekstrak etanol temulawak selama 5 hari meliputi warna, kekeruhan dan endapan .

4. Pemeriksaan Distribusi dan Ukuran Partikel

Pemeriksaan ukuran partikel dengan menggunakan alat particle sizer .

5. Pemeriksaan Morfologi Partikel

Pemeriksaan morfologi partikel dengan menggunakan alat scanning electron microscope (SEM).

6. Pemeriksaan Potensial Zeta 
Pemeriksaan zeta potensial dengan menggunakan alat pengukur zeta sizer (Farida,Rahmat,2018).

7. Uji Aktifitas Antibakteri Ekstrak Etanol Temulawak dan Nanopartikel Ekstrak Etanol Temulawak terhadap Bakteri Propionibacterium acne

Media Mueller Hinton Agar $25 \mathrm{~mL}$ ditambahkan suspensi bakteri 25\% T sebanyak $1 \mathrm{~mL}$ (cara : bakteri $25 \% \mathrm{~T}$ didapatkan dengan cara mengukur suspensi bakteri dalam kaldu pepton, menggunakan spektrofotometer UV-VIS hingga didapatkan hasil pengukuran sebesar 25\% T), homogenkan dan diamkan selama 5 menit pada suhu kamar dan pada keadaan tertutup. Di dalam ekstrak etanol temulawak dan nanopartikel ekstrak etanol temulawak yang telah dilarutkan dengan $1 \mathrm{ml}$ etanol, direndam kertas cakram steril. Kertas cakram steril diletakkan pada permukaan media nutrient agar. Diinkubasi pada suhu $37^{\circ} \mathrm{C}$ pada inkubator selama 24 jam. Daerah bening disekitar kertas cakram menunjukkan adanya zona hambat bakteri (Balouir,2016; Arullappan,2009; Bhalodia,2011).

\section{HASIL DAN PEMBAHASAN}

Dari data hasil optimasi penambahan Na-TPP sebagai cross-linker pada pembuatan nanopartikel ekstrak temulawak berdasarkan Tabel 1, didapatkan volume optimum adalah $20 \mathrm{~mL}$ yang menunjukkan terbentuknya nanopartikel. Pada penambahan $18 \mathrm{~mL}$ Na-TPP belum terjadi perubahan warna menjadi hijau kebiruan pada ekstrak yang artinya belum terbentuk nanopartikel. Sedangkan pada penambahan $22 \mathrm{ml} \mathrm{Na-TPP}$ telah terjadi perubahan warna namun terbentuk endapan melayang pada ekstrak. Hal ini kemungkinan karena Na-TPP terlalu banyak berinteraksi dengan kitosan sehingga mengakibatkan partikel yang terbentuk terlalu besar (Nastiti,2015).

Tabel I. Optimasi volume Na-TPP sebagai cross-linker pembuatan nanopartikel

\begin{tabular}{cl}
\hline Volume Na-TPP $(\mathbf{m L})$ & \multicolumn{1}{c}{ Hasil } \\
\hline 18 & Belum terjadi perubahan warna \\
20 & Sudah terjadi perubahan warna \\
22 & Terjadi perubahan warna, terdapat endapan \\
\hline
\end{tabular}

Ekstrak dilarutkan dalam pelarut campur etanol, propilenglikol dan DMSO karena ekstrak mempunyai banyak komponen yang harus bercampur baik dengan larutan kitosan agar bisa masuk ke dalam nanopartikel yang terbentuk. Hasil optimasi jumlah dan rasio pelarut yang digunakan belum mampu melarutkan ekstrak dengan sempurna sehingga perlu proses penyaringan untuk menghilangkan bagian yang tidak terlarut yang merupakan senyawa nonpolar. Penambahan tripolifosfat pada campuran larutan ekstrak dan larutan kitosan bertujuan untuk pembentukan nanopartikel dengan metode gelasi ionik. Kitosan akan bertaut silang dengan bantuan tripolifosfat karena muatan positif dari kitosan akan berinteraksi dengan muatan negatif dari tripolifosfat. Sementara itu, komponen ekstrak akan terjebak dalam matriks kitosan yang bertautsilang. Dengan pengaturan kecepatan pengadukan dan penambahan larutan tripolifosfat maka akan terbentuk nanopartikel (Mardliyati, El Muttaqien, Setyawati, 2012).

Terbentuknya nanopartikel ditandai dengan kekeruhan dan perubahan warna menjadi sedikit kehijauan. Dilanjutkan pengadukan selama 15 menit agar didapat suspensi nanopartikel yang stabil. Kemudian diamati kestabilannya selama 5 hari yang meliput warna, kekeruhan, dan endapan.

Tabel II. Hasil penamatan nanopartikel ekstrak temulawak

\begin{tabular}{llllll}
\hline \multirow{2}{*}{ Parameter } & \multicolumn{5}{c}{ Hari Ke- } \\
\cline { 2 - 6 } & \multicolumn{1}{c}{$\mathbf{1}$} & \multicolumn{2}{c}{$\mathbf{3}$} & \multicolumn{1}{c}{$\mathbf{4}$} & \multicolumn{1}{c}{$\mathbf{5}$} \\
\hline Warna & Kuning & Kuning & Kuning & Kuning & Kuning \\
& muda & muda & muda & muda & muda \\
Kekeruhan & Stabil & Stabil & Stabil & Stabil & Stabil \\
Endapan & Tidak ada & Tidak ada & Tidak ada & Tidak ada & Tidak ada \\
\hline
\end{tabular}


Dari hasil pemeriksaan distribusi dan ukuran partikel menggunakan alat Delsa ${ }^{\mathrm{TM}}$ Nano dengan tiga kali pengulangan didapatkan hasil sebagai berikut :

Tabel III. Hasil ukuran partikel nanopartikel

\begin{tabular}{cccc}
\hline Pengulangan ke- & $\begin{array}{c}\text { Ukuran rata- } \\
\text { rata }(\mathbf{n m})\end{array}$ & $\begin{array}{c}\text { Standard } \\
\text { deviasi }\end{array}$ & $\begin{array}{c}\text { Indeks } \\
\text { polidispersitas }\end{array}$ \\
\hline 1 & 62,6 & 16,3 & 0,384 \\
2 & 41,1 & 71,2 & 0,367 \\
3 & 54,0 & 14,0 & 0,401 \\
Rata-rata & 52,57 & - & - \\
\hline
\end{tabular}

Nanopartikel ekstrak temulawak memiliki ukuran partikel rata-rata yakni 52,57 nm dengan tiga kali proses pengulangan. Hal ini menunjukan bahwa nanopartikel dari ekstrak temulawak yang dibuat telah memenuhi syarat, dimana suatu partikel dikatakan nanopartikel bila berada dalam rentang 1$1000 \mathrm{~nm}$. Distribusi ukuran partikel dinyatakan dalam indeks polidispersitas. Rentang polidispersitas berada antara 0 sampai dengan 1 . Nilai polidispersitas yang baik ialah mendekati 0 dimana semakin mendekati 0 semakin homogen. Nanopartikel ekstrak temulawak memiliki indeks polidispersitas terletak antara 0,3-0,4. Hal ini menunjukan bahwa nanopartikel ekstrak temulawak terdispersi relatif homogen.

Tabel IV. Hasil evaluasi potensial zeta

\begin{tabular}{cc}
\hline Pengulangan & Zeta potensial $(\mathbf{m V})$ \\
\hline 1 & $-42,11$ \\
2 & $-53,79$ \\
3 & $-38,64$ \\
Rata-rata & $-44,84$ \\
SD & 7,93 \\
\hline
\end{tabular}

Dengan adanya kesamaan dari tiap partikel bermuatan (-) negatif dari nanopartikel ekstrak temulawak, maka gaya tolak menolak antar partikel semakin besar. Sehingga kemungkinan terbentuknya agregat dari nanopartikel yang terdispersi di dalam sistem suspensi berkurang. Efek ini berhubungan dengan pengikatan gugus anionik oleh gugus amin yang panjang dari kitosan untuk menjadi nilai elektrik yang tinggi sehingga dapat mencegah agregasi.

Hasil pemeriksaan morfologi partikel dari nanopartikel ekstrak temulawak dapat dilihat pada Gambar 1 dimana menunjukan partikel yang berbentuk sferis dan berukuran lebih besar akibat terjadinya penumpukan partikel yang terbentuk dari hasil pengering semprot.

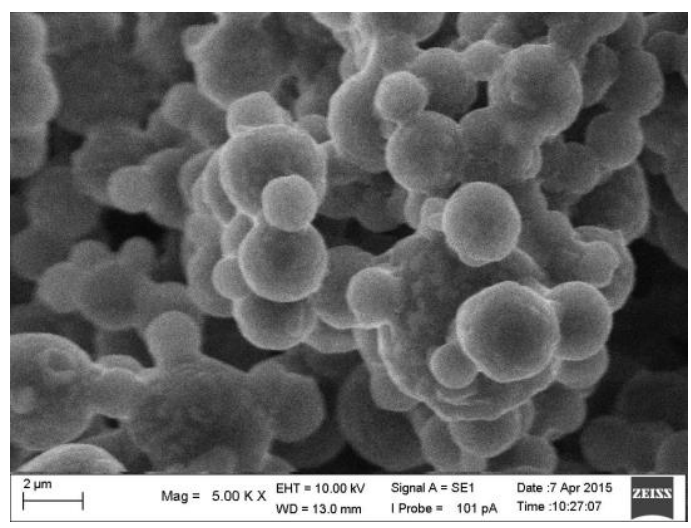

\section{Gambar 1. Nanopartikel hasil pengeringan semprot}

Berdasarkan hasil uji antibakteri pada konsentrasi ekstrak temulawak 0,5\% dan nanopartikel ekstrak temulawak setara dengan 0,5\% ekstrak terhadap Propionibacterium acne menggunakan metode 
difusi agar didapatkan hasil berupa daerah bening di sekitar cakram yang menunjukkan terjadi penghambatan pada pertumbuhan bakteri Propionibacterium acne oleh ekstrak temulawak dan juga nanopartikel ekstrak temulawak. Besarnya daerah hambat yang terjadi dituangkan dalam tabel 6 .

Tabel V. Hasil diameter daerah hambat

\begin{tabular}{lc}
\hline Bahan & Diameter daya hambat $(\mathbf{m m})$ \\
\hline Etanol & $4,90 \pm 0,27$ \\
Ekstrak temulawak & $11,23 \pm 0,18$ \\
Nanopartikel ekstrak temulawak & $11,79 \pm 0,83$ \\
\hline
\end{tabular}

Zona bening yang dihasilkan oleh serbuk nanopartikel ekstrak temulawak lebih besar bila dibandingkan dengan zona bening yang dihasilkan oleh ekstrak temulawak. Hal ini dikarenakan terjadinya perbedaan ukuran partikel. Serbuk nanopartikel memiliki ukuran yang sangat kecil sehingga lebih efektif menembus dinding sel bakteri dan menghambat pertumbuhan bakteri. Senyawa kurkumin dalam ekstrak temulawak terlibat dalam aktivitas antibakteri dari ekstrak dan nanopartikel ekstrak temulawak (Salleh,2016; Oon,2015; Sylvester,2015 ).

\section{KESIMPULAN}

Kitosan dapat digunakan untuk pembentukan nanopartkel ekstrak temulawak dan dapat meningkatkan aktivitas antibakteri sehingga potensial untuk dikembangkan menjadi sediaan antijerawat.

\section{DAFTAR PUSTAKA}

Afifah, E. 2003. Sehat Dengan Ramuan Tradisional : Khasiat dan Manfaat Temulawak Rimpang Penyembuh Aneka Penyakit. Agromedia Pustaka. Jakarta .

Arullappan, S., Zakaria Z., Basri, D.F., 2009, Preliminary screening of antibacterial activity using crude extracts of Hibiscus rosa sinensis. Trop. Life. Sci. Res., 20, 109-118

Balouiri, M., Sadiki, M., Ibnsouda, S.K., 2016, Methods for in vitro evaluating antimicrobial activity: a review. J. Pharm. Anal., 6, 71-79

Bhalodia, N.R., Shukla, V.J., 2011, Antibacterial and antifungal activities from leaf extracts of Cassia fistula 1.: an ethnomedicinal plant, J. Adv. Pharm. Technol. Res. 2, 104-109

Farida, Y., Rahmat, D., 2018, Uji Aktivitas Antiinflamasi Nanopartikel Ekstrak Etanol Rimpang Temulawak (Curcuma xanthorrhiza Roxb.) dengan Metode Penghambatan Denaturasi Protein, Jurnal Ilmu Kefarmasian Indonesia, 16(2), 225-230

Iswandana, R., Anwar, E., Jufri, M.. 2012, Preparasi Nanogel Verapamil Hidroklorida Menggunakan Metode Gelasi Ionik antara Kitosan-Natrium Tripolofosfat Sebagai Sediaan Antihipertensi, Universitas Indonesia, Depok, 12-14.

Mardliyati, E., El Muttaqien, S., Setyawati, D.R., 2012, Sintesis nanopartikel kitosan-trypoly phosphate dengan metode gelasi ionik: pengaruh konsentrasi dan rasio volume terhadap karakteristik partikel. Prosiding Pertemuan Ilmiah Ilmu Pengetahuan dan Teknologi Bahan, Serpong, 90-93

Nastiti, Siahaan, P., 2015, Pengaruh Berat Molekul Kitosan terhadap Efisiensi Enkapsulasi BSA (Bovine Serum Albumin) Menggunakan Agen Crosslink Na-TPP, Jurnal Kimia Sains dan Aplikasi, 18 (3), 104-109

Oon, S.F., Nallappan, M., Tee, T.T., Shohaini S., Kassim N.K., 2015, Xanthorrhizol: a review of its pharmacological activities and anticancer properties, Cancer Cell. Int., 15, 2-15.

Ramdja, A.F., Aulia, R.M.A., Mulya, P., 2009, Ekstraksi kurkumin dari temulawak dengan menggunakan etanol. Jurnal Teknik Kimia, 16(3), 52-58.

Reiger, M.M. 2000. Harry's Cosmeticology. 8th ed. Chemcal Publishing Company. New York

Retno S.W. 1985. Temulawak Khasiat dan Aneka Kegunaannya. Universitas Padjajaran, Bandung.

Salleh, N.A.M., Ismail, S., Halim, M.R.A, 2016,. Effects of Curcuma xanthorrhiza extracts and their constituents on phase ii drug metabolizing enzymes activity, Pharmacogn. Res., 8:309-315.

Sylvester, W.S., Son R., Lew, K., Rukayadi, Y., 2015, Antibacterial activity of Java turmeric (Curcuma xanthorrhiza Roxb.) extract against Klebsiella pneumoniae isolated from several vegetables, Int. Food Res. J., 22, 1770-1776. 
